\title{
PENGARUH PENGETAHUAN KEWIRAUSAHAAN DAN DUKUNGAN SOSIAL KELUARGA PADA MINAT BERWIRAUSAHA SISWA SMK NEGERI 1 PAMEKASAN
}

\author{
Novi Trisnawati, Universitas Negeri Surabaya \\ novitrisnawati07@gmail.com
}

\begin{abstract}
ABSTRAK
Penelitian ini bertujuan untuk menganalisis pengaruh pengetahuan kewirausahaan dan dukungan sosial keluarga pada minat berwirausaha siswa. populasi penelitian ini adalah kelas XI tahun ajaran 2013-2014 dengan total 368 siswa. Pengambilan sampel mengunakan teknik simple random sampling sebanyak 191 siswa. teknik pengumpulan data menggunakan kuesioner dan dokumentasi. Penelitian ini merupakan penelitian kuantitatif dengan analisis regresi linear berganda. Hasil menunjukkan bahwa secara parsial tidak ada pengaruh pengetahuan kewirausahaan pada minat berwirausaha dan ada pengaruh dukungan sosial keluarga pada minat berwirausaha. Secara simultan terdapat pengaruh pengetahuan kewirausahaan dan dukungan sosial keluarga pada minat berwirausaha.

Kata Kunci: Pengetahuan Kewirausahaan, Dukungan Sosial Keluarga, Minat Berwirausaha
\end{abstract}

\section{ABSTRACT}

This study aims to analyze the influences of entrepreneurial knowledge and social family supports on students interest in entrepreneurship. Population of this study were students from grade XI, for academic year 2013-2014 with total 368 students. 191 samples were taken using simple random sampling. Data were collected by questionnaires and documentations. This study was using quantitative analysis with multiple linear regresion. The results showed that there are Partially, there is no effect of entrepreneurial knowledge on students interest in entrepreneurship, and where as there is effect of social family supports on students interest in entrepreneurship. Simultaneous effects betwen entrepreneurial knowledge and social family supports on students interest in entrepreneurship.

Keywords: entrepreneurial knowledge, social family supports, student interest in entrepreneurship

\section{PENDAHULUAN}

Jumlah penduduk di Indonesia pada tahun 2013 menurut data dari BPS Indonesia diperkirakan akan bertambah menjadi 250 juta orang dengan pertumbuhan penduduk 1,49 persen per tahun, sementara angka pengangguran hingga Agustus 2013 masih 7.388 .737 orang sedangkan angka kemiskinan hingga Maret 2013 masih 28,07 juta orang. Pengangguran dan kemiskinan masih menjadi permasalahan di Indonesia. Menurut Saiman (2009) Pengangguran dan kemiskinan terjadi karena perbandingan antara jumlah penawaran kesempatan 
kerja tidak sebanding dengan jumlah lulusan atau penawaran tenaga kerja baru di segala level pendidikan. Namun, jumlah pengangguran dan kemiskinan sebenarnya dapat diperkecil dengan keberanian membuka usaha-usaha baru atau berwirausaha. Sehingga dengan berwirausaha merupakan salah satu cara pembangunan perekonomian negara Indonesia agar lebih baik dan maju.

Pembangunan perekonomian akan lebih berhasil jika ditunjang oleh wirausahawan yang dapat membuka lapangan kerja karena kemampuan pemerintah sangat terbatas. Pemerintah tidak akan mampu menggarap semua aspek pembangunan karena sangat banyak membutuhkan anggaran belanja, personalia, dan pengawasan. Hal ini senada dengan pernyataan Sunter yang ditunjukkan oleh Manuere (2013) dalam penelitiannya yaitu Kewirausahaan merupakan elemen penting dalam dinamika ekonomi nasional dan dipandang sebagai mesin penggerak pertumbuhan ekonomi dan penciptaan lapangan kerja. Oleh karena itu, wirausaha merupkan potensi pembangunan, baik dalam jumlah maupun dalam mutu wirausaha itu sendiri.

Dalam rangka meningkatkan pembangunan ekonomi, khususnya pengembangan kewirausahaan di seluruh tanah air, Presiden Susilo Bambang Yudhoyono telah mencanangkan Gerakan Kewirausahaan Nasional (GKN) pada Pebruari 2011. Dengan adanya GKN diharapkan generasi muda memiliki minat untuk menjadi wirausahawan. Menurut Aprilianty (2012) Minat dapat didefinisikan sebagai sesuatu yang membangkitkan perhatian pada suatu hal. Minat mengindikasi apa yang diinginkan atau dilakukan orang atau apa yang mereka senangi. Seseorang yang berminat pada suatu hal, maka segala tindakan atau apa yang dilakukan akan mengarahkan pada minatnya tersebut.

Minat berwirausaha di Kabupaten Pamekasan ini mempunyai peluang yang besar untuk dikembangkan. Menurut data dari BPS Kabupaten Pamekasan kontribusi terbesar PDRB Kabupaten Pamekasan Tahun 2012 diperoleh dari sektor pertanian sebesar $48,35 \%$ sedangkan yang kedua sektor perdagangan, hotel dan restoran sebesar $18,13 \%$, dan sektor terbesar ketiga adalah sektor jasa-jasa sebesar 12,88. Hal ini menunjukkan Penduduk Pamekasan ini belum sepenuhnya mengoptimalkan sumber daya alam yang ada untuk dijadikan peluang bisnis. Padahal sektor perdagangan, hotel dan restoran di Pamekasan ini memiliki ciri khas tersendiri yaitu misalnya dalam sektor perdagangan adalah kain batik khas pamekasan yang hingga saat ini masih belum memberikan kontribusi yang lebih banyak dalam pembangunan perekonomian. Permasalahan ini disebabkan karena penduduk pamekasan yang berwirausaha batik khas pamekasan ini sangat terbatas padahal batik khas Pamekasan ini salah satu produk yang potensial untuk lebih dikembangan di Pamekasan. Selain itu minat dalam berwirausaha di Kabupaten Pamekasan ini masih rendah. Dengan adanya sumber daya alam yang potensial dapat berguna dengan baik maka dibutuhkan manusia yang memiliki jiwa dalam berwirausaha, karena akan mengembangkan potensi-potensi yang ada dan menambah minat berwirausaha penduduk Pamekasan. Sehingga akan menjadi peluang untuk berwirausaha dan secara tidak langsung menambah pendapatan ekonomi penduduk Pamekasan.

Mengembangkan minat berwirausaha sebaiknya dimulai dari para remaja. Hal ini dikarenakan mereka sebenarnya memiliki ide-ide yang masih baru dan kreatif. Oleh karena itu peran Sekolah Menengah Kejuruan (SMK) yang ada di Pamekasan mempunyai peluang untuk mengembangkan kewirausahaan dan 
membangun perekonomian dengan memanfaatkan tahap perkembangan remaja, mendidik siswa agar berminat berwirausaha. Upaya untuk mengembangkan minat berwirausaha di SMK Pamekasan ini salah satunya dengan adanya pembelajaran Kewirausahaan. Menurut Sarwono (2011) Tahap perkembangan remaja akhir ditandai dengan adanya minat yang makin mantap terhadap fungsi-fungsi intelek. Selain itu sekolah berperan besar dan strategis dalam mengubah, sikap siswa dari mencari kerja menjadi pencipta lapangan kerja (wirausaha). Menurut Peraturan Pemerintah No. 66 Tahun 2010, Sekolah Menengah Kejuruan (SMK) merupakan salah satu bentuk pendidikan formal kejuruan pada jenjang pendidikan menengah. SMK merupakan pendidikan menengah kejuruan sebagai lanjutan dari SMP, MTs atau bentuk lain yang sederajat/diakui sama/setara SMP atau MTs.

Berdasarkan pengamatan, lulusan SMK Negeri 1 Pamekasan, selain melanjutkan ke perguruan tinggi mereka bekerja tidak sesuai dengan latar belakang pendidikan sesuai dengan jurusannya masing-masing, pekerjaan yang dilakukan siswa setelah lulus seperti bekerja di bengkel, petani, dan tenaga kerja yang bekerja di luar negeri, dan banyak pula yang masih menganggur. Dari gambaran sementara ini, masih belum banyak lulusan SMK Negeri 1 Pamekasan memilih karir wirausaha apalagi wirausaha yang sesuai dengan bidangnya. Sehingga sangat perlu dikaji apakah siswa SMK Negeri 1 Pamekasan masih banyak yang belum berminat memilih karir sebagai wirausahawan. Padahal peluang wirausahawan di daerah pamekasan saat ini terbuka lebih luas karena sejak dibangunnya jembatan suramadu maka jalur transportasi dari surabaya menuju madura ataupun sebaliknya lebih mudah untuk dijangkau.

Minat siswa untuk berwirausaha tidak bisa timbul begitu saja tanpa ada faktor-faktor yang mendukungnya. Menurut Abdullah (2013) menyebutkan bahwa minat berwirausaha dipengaruhi oleh (1) Socio-Demography, (2) Attitudes, (3) Acceptance, (4) Knowledge.

Minat seseorang dalam berwirausaha juga dipengaruhi oleh pengetahuan tentang kewirausahaan itu sendiri. Pembekalan pengetahuan kewirausahaan kepada siswa SMK sangat perlu dilakukan. Semakin tinggi pengetahuan kewirausahaan siswa SMK akan semakin terbuka wawasannya tentang kewirausahaan. Hal tersebut sesuai dengan yang diungkapkan Suryana (2009) bahwa syarat utama untuk menjadi wirausahawan yang sukses adalah memiliki jiwa dan watak kewirausahaan sedangkan jiwa dan watak dipengaruhi ketrampilan, kemampuan atau kompetensi yang mana kompetensi tersebut ditentukan oleh pengetahuan dan pengalaman usaha.

Selain itu penelitian yang dilakukan oleh Aprilianti (2012) menunjukkan bahwa pengetahuan kewirausahaan secara positif dan signifikan berpengaruh terhadap minat berwirausaha, hendaknya pengetahuan kewirausahaan siswa ditindak lanjuti dengan kegiatan-kegiatan praktek kewirausahaan. Agar siswa tidak hanya memiliki pengetahuan tetapi juga memiliki ketrampilan yang mendukung pengetahuannya tersebut. Sehingga minat siswa untuk berwirausaha akan semakin mantap. Hal ini sesuai dengan penelitian Abdullah (2013) menyatakan bahwa pengetahuan merupakan faktor yang penting dalam menumbuhkan minat berwirausaha pada remaja dan pengetahuan dapat berjalan dengan baik apabila juga menyeimbangkan ketrampilan berwirausaha sebagai persiapan untuk mendirikan usaha sendiri. 
Upaya yang sama coba dilakukan oleh SMK Negeri 1 Pamekasan untuk meningkatkan penguasaan pengetahuan bagi siswa. Mata pelajaran Kewirausahaan pada kelas X diberikan pemahaman tentang Mengaktualisasikan sikap dan perilaku wirausaha dan Menerapkan Jiwa Kepemimpinan sedangkan pada kelas XI semester 1 yaitu merencanakan usaha kecil/mikro. Pada kelas XI semester 1 para siswa lebih banyak melakukan praktik berwirausaha daripada menerima materi dikelas. Hal ini diperuntukkan memberikan suatu pengetahuan dasar dan pengalaman dalam berwirausaha. Mengingat penguasaan pengetahuan kewirausahaan siswa kelas XI SMK Negeri 1 Pamekasan dirasakan masih sangat kurang karena mata pelajaran kewirausahaan merupakan mata pelajaran yang baru dikenal oleh mereka di bangku SMK selain itu, model pembelajaran yang digunakan untuk mata pelajaran kewirausahaan masih berfokus pada guru yang menerangkan sedangkan siswa hanya mendengarkan.

Faktor lain yang berpengaruh terhadap minat siswa dalam berwirausaha adalah dukungan sosial keluarga. Menurut Costa (2009) menyatakan bahwa dukungan sosial keluarga merupakan faktor yang menentukan dalam minat berwirausaha siswa. Peran keluarga juga sangat penting dalam menumbuhkan minat berwirausaha bagi para siswa. Pendidikan berwirausaha dapat berlangsung sejak usia dini dalam lingkungan keluarga. Melalui keluarga pola pikir kewirausahaan terbentuk, minat berwirausaha tumbuh dan berkembang dengan baik pada seseorang yang hidup dan tumbuh di lingkungan keluarga wirausahawan. Hal ini sesuai dengan Izhar (2012) menyatakan bahwa keluarga memiliki fungsi yang signifikan dalam bidang kewirausahaan untuk mengambil suatu keputusan.

Pada kenyataannya sebagian besar kondisi keluarga belum kondusif dalam pembentukan minat anak dalam berwirausaha. Hal ini disebabkan oleh banyak faktor, antara lain: keterbatasan pengetahuan orang tua, tidak ada modal, dan pola pikir dalam keluarga menjadi PNS atau karyawan lebih aman daripada menjadi wirausahawan. Fenomena yang terjadi di SMK Negeri 1 Pamekasan berkaitan dengan dukungan sosial keluarga masih banyak siswa yang tidak mendapatkan dukungan dari keluarga, karena rata-rata mata pencaharian orang tua siswa adalah petani.

Dari keterangan diatas dapat dijelaskan bahwa dengan memiliki pengetahuan kewirausahaan yang cukup dan didukung dengan adanya dukungan sosial dari keluarga maka besar kemungkinannya siswa dapat memiliki minat berwirausaha yang kuat, yang diharapkan nantinya akan memberikan semangat untuk melakukan wirausaha. Oleh karena, itu perlu adanya penelitian untuk mengidentifikasi faktor yang mendorong minat berwirausaha mahasiswa mengingat pentingnya kewirausahaan bagi kesejahteraan ekonomi dan sosial Hal inilah yang mendorong penulis untuk melakukan penelitian dengan judul "Pengaruh Pengetahuan Kewirausahaan dan Dukungan sosial keluarga Pada Minat Berwirausaha Siswa SMK Negeri 1 Pamekasan."

Suryana (2013) menyatakan bahwa wirausahawan adalah seseorang yang menciptakan suatu bisnis baru dalam menghadapi risiko dan ketidakpastian. Hal tersebut bermaksud untuk memperoleh keuntungan dan pertumbuhan dengan cara mengidentifikasi peluang dan mengkombinasikan sumber-sumber daya yang diperlukan untuk memanfaatkan peluang tersebut. Esensi dari kewirausahaan adalah menciptakan nilai tambah di pasar melalui proses kombinasi sumber daya 
dengan cara-cara baru dan berbeda. Izhar (2012) menyatakan bahwa kewirausahaan merupakan prosedur untuk memulai usaha, mengelola sumber daya yang penting, menghadapi tantangan, serta adanya inovasi yang sistematis sesuai dengan tujuan dan terorganisir mencari perubahan.

Minat adalah suatu rasa lebih suka dan rasa ketertarikan pada suatu hal atau aktivitas, tanpa ada yang menyuruh. Menurut Slameto (2010) minat pada dasarnya adalah "penerimaan akan sesuatu hubungan antara diri sendiri dengan sesuatu di luar diri. Semakin kuat atau dekat hubungan tersebut semakin besar minat". Berbeda halnya dengan apa yang dikemukakan Sujanto (2001) minat ialah suatu pemusatan perhatian yang tidak disengaja yang terlahir dengan penuh kemauannya dan yang tergantung dari bakat dan lingkungannya.

Sedangkan menurut Sanjaya (2005) mengemukakan bahwa minat adalah kecenderungan seseorang untuk melakukan suatu tindakan atau perbuatan. Pendapat Sanjaya ini diperkuat oleh Djaali (2011) menyatakan bahwa minat pada dasarnya adalah penerimaan akan suatu hubungan antara diri sendiri dengan sesuatu yang ada di luar. Minat dapat ditunjukkan dengan adanya ekspresi melalui pernyataan yang menunjukkan bahwa siswa lebih menyukai suatu hal daripada lainnya dan dapat juga dimanifestasikan melalui partisipasi dalam suatu aktifitas. Menurut Hurlock (2010) menyatakan bahwa minat terbagi menjadi 3 aspek yaitu: aspek kognitif, aspek afektif, dan aspek psikomotor.

Pendapat yang di kemukakan (Putra, 2009) menerangkan bahwa "Minat berwirausaha adalah keinginan, ketertarikan, serta kesediaan untuk bekerja keras atau berkemauan keras untuk berusaha secara maksimal untuk memenuhi kebutuhan hidupnya tanpa merasa takut dengan resiko yang akan terjadi, serta berkemauan keras untuk belajar dari kegagalan". Sedangkan menurut Yuwono (2008) minat berwirausaha yaitu rasa tertariknya seseorang untuk melakukan kegiatan usaha yang mandiri dengan keberanian mengambil resiko. Minat tinggi berarti kesadaran bahwa wirausaha melekat pada dirinya sehingga individu lebih banyak perhatian dan lebih senang melakukan kegiatan wirausaha. Di dalam minat berwirausaha terdapat faktor-faktor yang mempengaruhi minat berwirausaha yaitu menurut Abdullah (2013) menyatakan ada 4 faktor yang mempengaruhi minat dalam berwirausaha yaitu: Sosial-Demografi, sikap, dukungan, dan pengetahuan.

Pengetahuan kewirausahaan memiliki peran yang sangat penting dalam kegiatan kewirausahaan. Menurut Hisrich (2008), pengetahuan kewirausahaan adalah dasar dari sumber daya kewirausahaan yang terdapat didalam diri individu Sedangkan menurut Suryana (2009) pemgetahuan kewirausahaan adalah pengetahuan yang dimiliki oleh seseorang yang sangat diperlukan terutama untuk: menghasilkan produk atau jasa baru, menghasilkan nilai tambah baru, merintis usaha baru, pelakukan proses/teknik baru, mengembangkan organisasi baru.

Di SMK pengetahuan kewirausahaan diberikan melalui pelajaran kewirausahaan dan kegiatan ekstrakurikuler yang biasanya bekerjasama dengan koperasi sekolah dan unit produksi. Pelajaran kewirausahaan di SMK diberikan dengan tujuan untuk Memahami dunia usaha dalam kehidupan sehari-hari, terutama yang terjadi di lingkungan masyarakat, Berwirausaha dalam bidangnya, Menerapkan perilaku kerja prestatif dalam kehidupannya, dan Mengaktualisasikan sikap dan perilaku wirausaha. 
Pengetahuan merupakan hasil dari usaha manusia untuk tahu. Pengertian lain dari pengetahuan yang diambil dari Wikipedia adalah"informasi atau maklumat yang diketahui atau disadari oleh seseorang”. Dalam kamus besar Bahasa Indonesia (2005) arti "Pengetahuan adalah segala sesuatu yang diketahui atau berkenaan dengan suatu hal". Formulasi Plato (Kuntowicaksono, 2012) menyatakan bahwa pengetahuan sebagai "keyakinan yang benar dibenarkan." Namun ada ada definisi yang disepakati tunggal pengetahuan saat ini, maupun prospek satu, dan masih ada banyak teori yang bersaing. Pengetahuan akuisisi melibatkan proses kognitif yang kompleks: persepsi, pembelajaran, komunikasi, asosiasi dan penalaran. Pengetahuan Istilah ini juga digunakan untuk berarti pemahaman subjek percaya diri dengan kemampuan untuk menggunakannya untuk tujuan tertentu jika sesuai. Sedangkan menurut Othman yang disebutkan oleh Abdullah (2013) Pengetahuan dapat menyebabkan kemampuan lebih banyak untuk kaum muda sebagai persiapan untuk mendirikan bisnis mereka sendiri. Selain itu menurut Silva yang disebutkan oleh Abdullah (2013) menyatakan bahwa Pengetahuan juga telah menjadi faktor kunci dalam mempengaruhi persepsi, dan tren ini direncanakan akan ditingkatkan.

Demikian halnya dengan pengetahuan kewirausahaan, juga memiliki peran yang sangat penting kegiatan kewirausahaan. Menurut Hisrich (2008), pengetahuan kewirausahaan adalah dasar dari sumber daya kewirausahaan yang terdapat didalam diri individu Sedangkan menurut Suryana (2009) pemgetahuan kewirausahaan adalah pengetahuan yang dimiliki oleh seseorang yang sangat diperlukan terutama untuk: menghasilkan produk atau jasa baru, menghasilkan nilai tambah baru, merintis usaha baru, pelakukan proses/teknik baru, mengembangkan organisasi baru.

Di SMK pengetahuan kewirausahaan diberikan melalui pelajaran kewirausahaan dan kegiatan ekstrakurikuler yang biasanya bekerjasama dengan koperasi sekolah dan unit produksi. Pelajaran kewirausahaan di SMK diberikan dengan tujuan untuk Memahami dunia usaha dalam kehidupan sehari-hari, terutama yang terjadi di lingkungan masyarakat, Berwirausaha dalam bidangnya, Menerapkan perilaku kerja prestatif dalam kehidupannya, dan Mengaktualisasikan sikap dan perilaku wirausaha.

Pengetahuan kewirausahaan yang diperoleh siswa diharapkan akan membuka wawasan siswa dalam berwirausaha. Sebagaimana yang diungkapkan oleh (Suryana, 2009) menyatakan bahwa "kebanyakan responden menjadi wirausaha karena didasari oleh pengalaman sehingga ia memiliki jiwa dan watak kewirausahaan". Untuk menjadi wirausaha yang berhasil syarat utama yang harus dimiliki yaitu memiliki jiwa dan watak kewirausahaan. Jiwa dan watak kewirausahaan tersebut dipengaruhi oleh ketrampilan dan kemampuan atau kompetensi. Kompetensi itu sendiri dtentukan oleh pengetahuan dan pengalaman usaha. Kompetensi kewirausahaan yang diberikan kepada siswa yaitu merencanakan Usaha Kecil/Mikro.

Pengetahuan kewirausahaan merupakan salah satu aspek penting dalam berwirausaha hal ini dikarenakan dengan memiliki pengetahuan yang memadai atau cukup, maka seseorang akan dapat mengelola usaha dengan baik. Kuntowicaksono (2012) menyatakan bahwa implikasi pengetahuan tersebut dapat diartikan bahwa seorang siswa akan mempunyai minat berwirausaha apabila siswa tahu secara benar tentang seluruh karakteristik dalam dunia usaha. Hasil penelitian 
Kuntowicaksono (2012) menunjukkan bahwa pengetahuan wirausaha tidak berpengaruh secara signifikan terhadap minat berwirausaha. Hasil tersebut mempunyai makna bahwa peningkatan pengetahuan wirausaha tidak akan meningkatkan minat untuk berwirausaha. Hal ini disebabkan karena dalam menjalankan usaha tidak hanya mengandalkan pengetahuan saja akan tetapi memerlukan sebuah strategi-strategi tertentu agar usaha yang dijalankan tetap berjalan dengan baik dan berhasil.

Hal ini berbeda dengan hasil penelitian Yuliyaningsih (2013) menyebutkan bahwa adanya hubungan yang positif dan signifikan antara pengetahuan kewirausahaan dengan minat berwirausaha siswa kelas XII Akuntansi SMK Negeri 1 Sukoharjo. Sehingga minat berwirausaha siswa akan meningkat jika pengetahuan kewirausahaan siswa meningkat, dengan adanya mata pelajaran kewirausahaan yang diajarkan baik secara teori maupun praktik sangat dibutuhkan oleh para siswa untuk memantapkan dan mempersiapkan keinginan mereka dalam berwirausaha. Sehingga, berdasarkan beberapa penjelasan di atas, maka dapat ditarik kesimpulan bahwa pengetahuan kewirausahaan mempengaruhi minat berwirausaha.

Dukungan merupakan salah satu bentuk interaksi sosial yang didalamnya terdapat hubungan yang saling memberi dan menerima bantuan sehingga dapat memberikan suatu perhatian. Menurut Rogers (2004) akan memungkinkan seorang anak untuk mengembangkan kekuatannya; memberikan keberanian untuk 'gagal' dan belajar dari kegagalan. Sedangkan keluarga menurut Ahmadi (2007) merupakan suatu kesatuan sosial yang terkecil yang terdiri dari suami, istri, dan jika ada anak-anak dan didahului oleh perkawinan. Dalam keluarga akan terjadi interaksi sosial dimana seorang anak pertama-tama belajar memperhatikan keinginan-keinginan orang lain, belajar bekerja sama, saling membantu, disini anak belajar memegang peranan sebagai makhluk sosial yang mempunyai normanorma dan kecakapan-kecakapan tertentu dalam pergaulannya dengan orang lain.

Dukungan sosial keluarga menurut Friedman yang diungkapkan oleh Agustini (2013) berpendapat bahwa orang yang bersifat mendukung selalu siap memberikan pertolongan dan bantuan jika diperlukan. Baik keluarga inti maupun keluarga besar berfungsi sebagai sistem pendukung bagi anggota-anggotanya, baik dalam bentuk emosional, instrumental, informative maupun penghargaan. Menurut kuntjoro dalam Handayani (2010) dukungan sosial yaitu adanya pemberian informasi baik secara verbal maupun non verbal, pemberian bantuan tingkah laku atau materi yang didapat dari hubungan sosial yang akrab atau hanya disimpulkan dari keberadaan mereka yang membuat individu merasa diperhatikan, bernilai atau menguntungkan bagi kesejahteraan individu yang menerimanya. Sedangkan menurut Izhar (2012) dukungan sosial keluarga adalah salah satu dukungan sosial yang paling penting dan mendorong seseorang untuk mengambil resiko dalam mengambil keputusan.

Sebuah keluarga memiliki fungsi yang signifikan hal ini seperti apa yang diungkapkan oleh Izhar (2012) keluarga mempunyai peran dalam tampil eskalasi kualitas kewirausahaan dalam mengambil risiko. Costa (2009) menyatakan bahwa berdasarkan sudut pandang dari Filion, dukungan sosial keluarga sangat relevan pada awal pengembangan visi kewirausahaan dalam menciptakan bisnis baru. Selain itu hasil penelitian Costa (2009) menyatakan bahwa dukungan yang diberikan keluarga dan teman-teman serta adanya penguasaan ketrampilan 
merupakan faktor yang menentukan secara konsisten minat kewirausahaan siswa. Hasil penelitian lain yaitu Hermina (2011) menyatakan bahwa dukungan sosial keluarga dan masyarakat terhadap minat untuk menjadi wirausahawan menunjukkan hasil terbanyak menyatakan bahwa dukungan sosial keluarga sangat berperan untuk menjadi wirausaha.

\section{METODE PENELITIAN}

Pendekatan penelitian yang digunakan dalam penelitian ini adalah penelitian kuantitatif. Sedangkan jenis penelitian yang digunakan adalah penelitian tingkat eksplanasi (level of explanation). Berdasarkan tingkat eksplanasi, penelitian ini termasuk penelitian asosiatif. Variabel yang digunakan dalam penelitian ini adalah pengetahuan kewirausahaan (X1) dan Dukungan sosial keluarga (X2) pada minat berwirausaha (Y) siswa kelas XI di SMKN 1 Pamekasan.

Populasi dalam penelitian ini adalah siswa kelas XI SMK Negeri 1 Pamekasan sebanyak 368 siswa. Jumlah sampel yang digunakan sebanyak 191 siswa. Sampel ditentukan dengan menggunakan rumus Slovin. Teknik pengambilan sample yang digunakan adalah Teknik probability sampling dengan jenis simple random sampling. Menurut Sugiyono (2011) Simple random sampling yaitu cara pengambilan sampel dari anggota populasi dengan menggunakan acak tanpa memperhatikan strata atau tingkatan dalam anggota populasi tersebut. Hal ini dilakukan apabila populasi dianggap sejenis (homogen).

Data dikumpulkan menggunakan kuesioner dan dokumentasi. Dokumentasi digunakan untuk mengumpulkan data dari variabel pengetahuan kewirausahaan dengan menggunakan hasil nilai rata-rata raport mata pelajaran kewirausahaan semester ganjil dan genap kelas XI tahun 2013/2014. Sedangkan kuesioner digunakan untuk mengumpulkan data dari variabel dukungan sosial keluarga dan minat berwirausaha. Kuesioner disusun berdasarkan variabel penelitian dan indikator penelitian dengan skala pengukuran instrument menggunakan skala likert. Berikut ini adalah indikator dari variabel dukungan sosial keluarga dan minat berwirausaha :

1. Indikator Dukungan Sosial Keluarga terdiri dari:
a. Emosional
b. Penilaian
c. Informatif
d. Instrument

2. Indikator Minat Berwirausaha terdiri dari:
a. Pengungkapan/ucapan
b. Tindakan/perbutan
c. Menjawab sejumlah pertanyaan

Teknik analisis menggunakan analisis regresi linear berganda dengan kriteria uji $\mathrm{F}$ dan uji t. Uji $\mathrm{F}$ digunakan untuk menguji signifikansi variabel pengetahuan kewirausahaan dan dukungan sosial keluarga pada minat berwirausaha secara simultan. Sedangkan uji t digunakan untuk menguji signifikansi pengetahuan kewirausahaan dan Dukungan sosial keluarga pada minat berwirausaha secara parsial. 


\section{HASIL PENELITIAN DAN PEMBAHASAN}

\section{Hasil Penelitian}

Model regresi yang diperoleh berdasarkan hasil penelitian, dapat dituliskan dalam betuk persamaan regresi sebagai berikut $Y=24,478-0,63 \mathrm{X} 1+0,375 \mathrm{X} 2$ + ei. Dari persamaan regresi tersebut, variabel bebas pengetahuan kewirausahaan memiliki pengaruh yang negatif. Hal ini berarti semakin baik pengetahuan kewirausahaan maka minat berwirausaha akan mengalami penurunan. Sedangkan variabel bebas dukungan sosial keluarga memiliki koefisien regresi dengan arah positif. Hal ini berarti semakin baik dukungan sosial keluarga akan meningkatkan minat berwirausaha. Hasil uji $F$ berdasarkan ANOVA atau uji statistik $F$, menunjukkan bahwa $\mathrm{F}$ hitung sebesar 20,353 dengan tingkat signifikansi kurang dari $5 \%$ yaitu 0,000 , hal ini berarti variabel pengetahuan kewirausahaan dan dukungan sosial keluarga secara simultan berpengaruh pada minat berwirausaha.

Besarnya koefisien korelasi adalah 0,422 berarti $17,8 \%$ minat berwirausaha dipengaruhi oleh pengetahuan kewirausahaan dan dukungan sosial keluarga. Sedangkan $82,2 \%$ dipengaruhi oleh faktor-faktor lain selain variabel dalam penelitian ini.

Uji t digunakan untuk mengetahui pengaruh pengetahuan kewirausahaan dan Dukungan sosial keluarga secara parsial pada minat berwirausaha. Uji parsial menunjukkan variabel pengetahuan kewirausahaan memiliki nilai t-hitung sebesar $-1,001$ dengan tingkat signifikan lebih besar dari pada 5\% yaitu 0,318. Artinya pengetahuan kewirausahaan (X1) secara parsial tidak berpengaruh signifikan pada minat berwirausaha (Y). Variabel dukungan sosial keluarga memiliki nilai thitung sebesar 6,232 dengan tingkat signifikan kurang dari $5 \%$ yaitu 0,000. Artinya dukungan sosial keluarga (X2) secara parsial berpengaruh signifikan pada minat berwirausaha $(\mathrm{Y})$.

\section{Pembahasan}

\section{Pengaruh Pengetahuan Kewirausahaan Pada Minat Berwirausaha}

Berdasarkan hasil analisis menunjukkan bahwa pengetahuan kewirausahaan tidak berpengaruh signifikan pada minat berwirausaha. Hasil tersebut mempunyai makna bahwa setiap perubahan variabel pengetahuan kewirausahaan (X1) akan berpengaruh negatif pada minat berwirausaha (Y). Nilai koefisien regresi negatif menunjukkan pengaruh yang timbul tidak searah, dimana setiap naiknya variabel pengetahuan kewirausahaan (X1) maka minat berwirausaha (Y) akan mengalami penurunan dengan asumsi variabel dukungan sosial keluarga adalah konstan.

Hasil penelitian ini mendukung teori dari lambing dalam Suryana (2009) bahwa "kebanyakan responden menjadi wirausaha karena didasari oleh pengalaman sehingga ia memiliki jiwa dan watak kewirausahaan". Oleh karena itu praktik kewirausahaan sangat penting untuk memberikan pengalaman siswa dalam berwirausaha.

Hasil penelitian ini juga mendukung hasil penelitian dari Kuntowicaksono (2012) yang menunjukkan bahwa pengetahuan wirausaha tidak berpengaruh signifikan terhadap minat berwirausaha, hal ini dikarenakan pengetahuan saja tidak cukup untuk menjadi modal seseorang dalam menjalankan wirausaha akan tetapi seseorang harus mampu melihat kondisi rill yang terjadi di lapangan atau 
dipasar sehingga dapat menentukan strategi-strategi yang akurat dalam menjalankan bisnis.

Hasil Penelitian ini tidak mendukung hasil penelitian dari Aprilianty (2012) yang menyatakan bahwa terdapat pengaruh positif dan signifikan pengetahuan kewirausahaan terhadap minat berwirausaha. Berarti minat berwirausaha akan meningkat apabila pengetahuan kewirausahaan ditingkatkan. Semakin tinggi pengetahuan kewirausahaa, semakin tinggi pula minat berwirausaha siswa. Selain itu, hasil penelitian yang tidak mendukung penelitian ini yaitu Yuliyaningsih (2013) menunjukkan bahwa terjadi hubungan antara pengetahuan kewirausahaan dengan minat berwirausaha pada siswa kelas XII Akuntansi SMK Negeri 1 Sukoharjo Tahun Pelajaran 2012/2013 adalah hubungan yang positif dan signifikan dengan tingkat korelasi sedang. Hal ini berarti, minat berwirausaha siswa akan meningkat jika pengetahuan kewirausahaan siswa meningkat.

Pengetahuan kewirausahaan tidak berpengaruh signifikan pada minat berwirausaha siswa SMK Negeri 1 Pamekasan didukung oleh temuan pada tahun ajaran 2012/2013 praktik kewirausahaan di SMK Negeri 1 Pamekasan dilaksanakan dengan baik tetapi pada tahun ajaran 2013/2014 praktik kewirausahaan tidak dapat dilaksanakan dengan utuh seperti tahun ajaran yang sebelumnya. Hal ini dikarenakan masa transisi kepala sekolah baru oleh karena itu kebijakan yang diterapkan juga berbeda dengan yang sebelumnya. Sehingga pada semester genap yang semestinya dilaksanakan praktik kewirausahaan tetapi pada kenyataannya para siswa waktunya lebih banyak untuk prakerin di perusahaan selama kurang lebih 3 bulan. Selain itu hal ini disebabkan karena pengetahuan kewirausahaan yang diterima oleh siswa hanya sebatas pemberian materi saja dan penugasan. Berdasarkan hasil penelitian diketahui bahwa tingginya nilai pengetahuan kewirausahaan siswa tidak diikuti oleh tingginya minat berwirausaha siswa SMK Negeri 1 Pamekasan. Pada pembelajaran kewirausahaan ini siswa hanya terbatas mendengarkan keterangan guru dan tidak betul-betul memahami materi yang diajarkan. Pengetahuan yang diberikan hanya teori saja, hal ini menyebabkan siswa mengalami kebosanan karena siswa menganggap pengetahuan kewirausahaan tidak menarik. Padahal semestinya pengetahuan kewirausahaan itu lebih bermakna apabila melaksanakan praktik kewirausahaam.

Selanjutnya kenyataan yang terjadi di lapangan, siswa mengikuti pelajaran kewirausahaan itu saja sudah sangat beruntung karena apabila siswa tidak menyukai pelajaran tersebut maka para siswa lebih memilih untuk tidak masuk kelas tetapi hal ini terkecuali untuk siswa jurusan akuntansi karena siswa akuntansi lebih serius dan giat dalam mengikuti pembelajaran. Pembelajaran kewirausahaan di SMK Negeri 1 Pamekasan pada kelas XI standar kompetensi yang diberikan adalah tentang merencanakan usaha kecil/ mikro. Pada semester ganjil materi yang dibahas yaitu tentang menganalisis peluang usaha dan menganalisis aspek-aspek perencanaan usaha. Meteode pembelajaran yang digunakan yaitu guru dalam penyampaian materi lebih banyak ceramah daripada praktik, tanya jawab dengan siswa dan penugasan. Sedangkan semester genap materi yang dibahas yaitu tentang menyusun proposal usaha. Sehingga kegiatan praktik kewirausahaan tidak dapat terlaksana dengan baik, para siswa hanya praktik membuat proposal usaha saja.

Selain itu, juga didukung oleh temuan pada sebagaian dari siswa mendapat nilai yang tinggi pada mata pelajaran kewirausahaan bukan karena mereka 
memahami pengetahuan yang diberikan tetapi, karena saat ujian para siswa hanya menghafalkan materi pelajaran. Setelah ujian selesai siswa lupa apa yang telah mereka pelajari dan kenyataannya sumber daya manusia siswa SMK Negeri 1 Pamekasan ini lemah. Nilai yang diperoleh tersebut telah dilakukan remidi beberapa kali karena untuk mencapai nilai diatas KKM. Oleh karena itu guru lebih cenderung untuk menilai siswa ke dalam penilaian sehari-hari yaitu penilaian kerajinan dan sikap.

Hasil temuan tersebut menunjukkan bahwa dalam pengetahuan kewirausahaan akan lebih baik dalam menumbuhkan minat berwirausaha karena di dalam menjalankan suatu usaha tidak hanya pengetahuan saja yang dibutuhkan, tetapi sebuah strategi dan pengalaman sangat dibutuhkan sehingga memperoleh hasil yang memuaskan. Hal tersebut sesuai dengan pendapat Abdullah (2013) yang menyatakan bahwa pengetahuan dan ketrampilan sangat dibutuhkan untuk menghadapi tantangan dan perubahan ekonomi dalam era globalisasi. Sehingga, dapat disimpulkan bahwa dalam penelitian ini pengetahuan kewirausahaan tidak berpengaruh pada minat berwirausaha siswa SMK Negeri 1 Pamekasan.

2. Pengaruh Dukungan Sosial Keluarga Pada Minat Berwirausaha

Berdasarkan hasil analisis menunjukkan bahwa dukungan sosial keluarga berpengaruh signifikan dan positif pada minat berwirausaha. Hasil tersebut mempunyai makna bahwa minat berwirausaha akan meningkat apabila dukungan sosial keluarga ditingkatkan. Semakin tinggi dukungan sosial keluarga, semakin tinggi pula minat berwirausaha siswa SMK Negeri 1 Pamekasan.

Hasil penelitian ini mendukung teori dan hasil penelitian sebelumnya, diantaranya dari Semiawan (2009) menyatakan bahwa pembangunan bangsa itu sebaiknya berasal dari dan dimulai dari rumah, di dalam kehidupan keluarga karena di rumahlah secara tidak langsung terjadi timbal balik ditumbuhkannya kepedulian, kesadaran, dan pengertian dasar tentang totalitas lingkungan. Selain itu, Izhar (2012) yang menyatakan bahwa Sebuah keluarga memiliki fungsi yang signifikan dan keluarga mempunyai peran dalam tampil eskalasi kualitas kewirausahaan dalam mengambil risiko. Hasil penelitian ini juga mendukung penelitian lain yang dilakukan oleh Hermina (2011) menyatakan bahwa dukungan sosial keluarga dan masyarakat terhadap minat untuk menjadi wirausahawan menunjukkan hasil terbanyak menyatakan bahwa dukungan sosial keluarga sangat berperan untuk menjadi wirausaha.

Dukungan sosial keluarga berpengaruh signifikan pada minat berwirausaha siswa SMK Negeri 1 Pamekasan didukung oleh temuan pada variabel dukungan sosial keluarga dalam penelitian ini lebih dominan didukung oleh indikator penilaian. Hal ini dapat ditunjukkan dari temuan bahwa sebagian besar siswa mendapatkan dukungan sosial dari keluarga berupa saling bekerja sama dalam kehidupan sehari-hari, menanamkan nilai-nilai keadilan dalam bertindak, dan sikap saling menghormati di dalam keluarga serta adanya dorongan untuk maju dari keluarga untuk mendirikan suatu usaha.

Selain itu, temuan yang lain pada variabel dukungan sosial keluarga ini yaitu pada indikator "instrumen" menunjukkan hasil paling lemah diantara indikator yang lainnya. Hal ini dapat ditunjukkan dari hasil temuan bahwa sebagian besar siswa tidak nebdapatkan bantuan dukangan moril dan keuangan dari keluarga yang berkaitan dengan kegiatan kewirausahaan. Hal ini dikarenakan berdasarkan data sebagain besar pekerjaan orang tua siswa adalah sebagai petani, 
oleh karena itu sebagian besar keadaan perekonomian keluarga siswa adalah perekonomian lemah. Selain itu hasil temuan juga menunjukkan sebagian besar siswa setelah lulus SMK lebih memilih untuk bekerja dengan alasan ingin membantu perekonomian keluarga.

Hasil temuan tersebut menunjukkan bahwa dukungan sosial keluarga terbukti dapat memberikan sumbangan positif untuk menumbuhkan minat berwirausaha siswa SMK Negeri 1 Pamekasan. Hal tersebut sesuai dengan pendapat Costa (2009) menyatakan bahwa dukungan yang diberikan keluarga dan teman-teman serta adanya penguasaan ketrampilan merupakan faktor yang menentukan secara konsisten minat kewirausahaan siswa. Sehingga dapat disimpulkan bahwa dalam penelitian ini dukungan sosial keluarga dapat terbukti menjadi faktor yang mempengaruhi minat berwirausaha siswa SMK Negeri 1 Pamekasan.

3. Pengaruh Pengetahuan Kewirausahaan dan Dukungan Sosial Keluarga Pada Minat Berwirausaha

Berdasarkan hasil penelitian Pengetahuan Kewirausahaan dan Dukungan Sosial Keluarga pada Minat Berwirausaha. Hipotesis ketiga yang menyatakan bahwa "Diduga pengetahuan kewirausahaan dan dukungan sosial keluarga berpengaruh pada minat berwirausaha siswa SMKN 1 Pamekasan" teruji kebenarannya. Hal ini berarti pengetahuan kewirausahaan (X1) dan dukungan sosial keluarga (X2) secara simultan atau bersama-sama bepengaruh signifikan pada minat berwirausaha $(\mathrm{Y})$.

Hasil penelitian ni mendukung teori dan hasil penelitian sebelumnya, diantaranya yang dilakukan oleh Abdullah (2013) yang menerangkan bahwa minat berwirausaha dipengaruhi oleh (1) Socio-Demography, (2) Attitudes, (3) Acceptance, (4) Knowledge. Selain itu, Putra (2012) menerangkan bahwa terdapat enam faktor yang menentukan minat mahasiswa manajemen untuk berwirausaha yaitu (1) faktor lingkungan, (2) faktor harga diri, (3) faktor peluang, (4) faktor kepribadian, (5) faktor visi, (6) faktor pendapatan dan percaya diri.

Hasil penelitian ini juga mendukung penelitian lain yang dilakukan oleh Hermina (2011) yang menyatakan bahwa pembelajaran mata kuliah kewirausahaan dilihat dari faktor intrinsik dan faktor ekstrinsik, ternyata secara keseluruhan mampu mempengaruhi minat mahasiswa menjadi wirausahawan. Selain itu keterlibatan dukungan keluarga untuk membentuk minat mereka menjadi wirausaha. Responden mengakui selain mendapatkan ilmu dari matakuliah kewirausahaan, proses pembelajaran ini melalui penanaman tentang nilai-nilai, pemahaman, jiwa, sikap dan perilaku juga menumbuhkan pemikiran dan karakteristik wirausaha dan hal ini mendukung minat mereka menjadi wirausaha.

Pengetahuan kewirausahaan dan dukungan sosial keluarga berpengaruh signifikan pada minat berwirausaha siswa SMK Negeri 1 Pamekasan didukung oleh temuan pada variabel minat berwirausaha dalam penelitian ini lebih dominan didukung oleh indikator "Tindakan". Hal ini dapat ditunjukkan dari temuan bahwa sebagian besar siswa merasa senang melakukan kegiatan yang berkaitan dengan berwirausaha hal ini ditunjukkan dengan mengikuti kegiatan pembelajaran kewirausahaan yang mana siswa tertarik saat guru menceritakan tentang contohcontoh wirausahawan yang sukses. Temuan selanjutnya sebagian besar siswa tidak mengikuti seminar, lomba yang berkaitan dengan kewirausahaan dan 
kegiatan lainnya yang berkaitan dengan kewirausahaan. Oleh karena itu minat berwirausaha siswa SMK Negeri 1 Pamekasan masih belum tumbuh dengan baik.

Selain itu, juga didukung oleh temuan yang sesuai dengan hasil analisis data yang menunjukkan bahwa pengetahuan kewirausahaan tidak berpengaruh signifikan pada minat berwirausaha yang disebabkan oleh pengetahuan kewirausahan hanya diperoleh dari pembelajaran kewirausahaan di kelas saja dengan penyampaian materi dan tidak ada pelaksanaan praktik berwirausaha. Sedangkan dukungan sosial keluarga berpengaruh signifikan pada minat berwirausaha tetapi besarnya pengaruh yang diberikan sangat lemah. Hal ini dapat ditunjukkan dari hasil temuan bahwa sebagian besar siswa mendapat dukungan saran, nasihat dan pengarahan dari keluarga untuk berwirausaha tetapi tidak didukung dengan dukungan moril dan keuangan untuk mendirikan suatu usaha.

Hasil temuan tersebut menunjukkan bahwa pengetahuan kewirausahaan dan dukungan sosial keluarga memberikan sumbangan positif pada menumbuhkan minat berwirausaha siswa SMK Negeri 1 Pamekasan. Hal tersebut sesuai dengan pendapat Abdullah (2013) yang menerangkan bahwa pengetahuan kewirausahaan dan dukungan sosial keluarga dapat memberikan sumbangan pada peningkatan minat berwirausaha remaja.

Sehingga, dapat disimpulkan bahwa pengetahuan kewirausahaan dan dukungan sosial keluarga secara simultan berpengaruh signifikan pada minat berwirausaha siswa SMK Negeri 1 Pamekasan.

\section{KESIMPULAN}

Kesimpulan dari pembahasan penelitian ini adalah sebagai berikut:

1. Tidak terdapat pengaruh pengetahuan kewirausahaan pada minat berwirausaha siswa kelas XI SMK Negeri 1 Pamekasan. Hal ini berarti pengetahuan kewirausahaan secara parsial tidak berpengaruh signifikan terhadap minat berwirausaha sehingga disimpulkan bahwa pengetahuan kewirausahaan yang tinggi tidak diikuti minat berwirausaha.

2. Terdapat pengaruh dukungan sosial keluarga pada minat berwirausaha siswa kelas XI SMK Negeri 1 Pamekasan. Hal ini berarti dukungan sosial keluarga secara parsial berpengaruh signifikan pada minat berwirausaha. Dukungan sosial keluarga yang baik ditunjukkan dalam bentuk adanya dukungan, perhatian dan pemberian contoh untuk saling bekerja sama sertan menanamkan nilai-nilai keadilan dalam bertindak.

3. Terdapat pengaruh pengetahuan kewirausahaan dan dukungan sosial keluarga pada minat berwirausaha siswa kelas XI SMK Negeri 1 Pamekasan. Hal ini menunjukkan bahwa pengetahuan kewirausahaan dan dukungan sosial keluarga secara simultan berpengaruh signifikan pada minat berwirausaha. Semakin tinggi pengetahuan kewirausahaan dan dukungan sosial keluarga maka semakin tinggi minat berwirausaha siswa SMK Negeri 1 Pamekasan. 


\section{DAFTAR RUJUKAN}

Abdullah, Abdul Aziz and Norhlilmatun Naem Sulaiman. 2013. Factors That Influence the Interest of Youths in Agricultural Entrepreneurship. International Journal of Business and Social Science. Vol, 4, No. 3; March 2013.

Agustini, Ni Nyoman Mestri., Nunuk Suryani, dan Pancrasia Murdani. 2013. Hubungan Antara Tingkat Pengetahuan Ibu dan Dukungan Keluarga dengan Cakupan Pelayanan Antenatal di Wilayah Kerja Puskesmas Buleleng I. Jurnal Magister Kedokteran Keluarga. Vol. 1, No. 1, Hal 67-79.

Aprilianty, Eka. 2012. Pengaruh Potensi Kepribadian Wirausaha, Pengetahuan, dan Lingkungan Terhadap Minat Berwirausaha Siswa SMK Rumpun Pertanian di Daerah Istimewa Yogyakarta.

BPS. 2013. Statistik Indonesia. Jakarta.

Costa, Francisco Jose Da., Alexandre Araujo Cavalcante Soares., and Diego Guilherme Bonfim. 2009. Factors of Influence On The Entrepreneurial Interest: An Analysis With Students Of Information Technology Related Courses. Journal of Information System and Technology Management, Vol. 6, No. 2, p 227-246, ISSN online: 1807-1775.

Handayani, Agustin. 2010. "Hubungan Kepuasan Kerja dan Dukungan Sosial dengan Persepsi Perubahan Organisasi”. INSAN. Vol. 12 No. 03, Desember 2010 .

Hermina, Utin Nina., Syarifah Novieyana dan Desvira Zain. 2011. Pengaruh Mata Kuliah Kewirausahaan Terhadap Minat Mahasiswaw Menjadi Wirausaha Pada Program Studi Administrasi Bisnis Politeknik Negeri Pontianak. Jurnal Eksos, Vol. 7, No. 2, hlm. 130-141.

Hisrich, R.D., Peters, M.P., and Shepherd, D.A. (2008). Kewirausahaan Edisi 7. Edisi Bahasa Indonesia. Jakarta : Salemba Empat.

Hurlock, Elizabeth. B. 2010. Psikologi Perkembangan: Suatu Pendekatan Sepanjang Rentang Kehidupan. Jakarta: Erlangga.

Izhar, Syed Tariq., Hasan Raza. 2012. The Role of Society in Nurturing Entrepreneurs in Pakistan. European Journal of Business and Management. Vol 4, No. 20.

Kuntowicaksono. 2012. Pengaruh Pengetahuan Wirausaha dan Kemampuan Memecahkan Masalah Wirausaha terhadap Minat Berwirausaha Siswa Sekolah Menengah Kejuruan. Journal of Economic Education 1 (1) (2012).

Manuere, Faitira., Kizito Danha and Tasara Majoni. 2013. Entrepreneurship Attitudes and Knowledge: A Survey of Fourth Year University Students. Interdisciplinary Journal of Contemporary Research in Business. January 2013, Vol. 4, No. 9.

Putra, Rano Aditia. 2012. Faktor-faktor Penentu Minat Mahasiswa Manajemen untuk Berwirausaha (Studi Mahasiswa Manajemen FE Universitas Negeri Padang). Jurnal Manajemen Volume. 01, Nomor. 01.

Rogers, Bill. 2004. Behaviour Recovery. Jakarta: PT Grasindo.

Saiman, Leonardus. (2009). Kewirausahaan. Teori, Praktik, dan kasus-kasus. Jakarta: Salemba Empat.

Sanjaya, Wina. 2005. Pembelajaran Dalam Implementasi Kurikulum berbasis Kompetensi. Jakarta: Kencana Prenada Media. 
Sarwono, Sarlito W. (2011). Psikologi Remaja (edisi revisi). Jakarta: Rajawali Pers.

Semiawan, Conny. 2009. Penerapan Pembelajaran Pada Anak. Jakarta: PT Indeks.

Sugiyono. 2011. Metode Penelitian Administrasi Dilengkapi dengan Metode $R \& D$. Bandung: CV. ALFABETA.

Sujanto. 2001. Psikologi Umum. Bandung: CV. ALFABETA.

Suryana. 2009. Kewirausahaan, Pedoman Praktis: Kiat dan Proses Menuju Sukses. Jakarta: Salemba Empat. . 2013. Kewirausahaan, Pedoman Praktis: Kiat dan Proses Menuju Sukses. Jakarta: Salemba Empat.

Slameto. 2010. Belajar dan Faktor-faktor yang Mempengaruhinya. Jakarta: Rineka Cipta.

Yuliyaningsih, Ika Pina., Susilaningsih, dan Jaryanto. 2013. Hubungan Pengetahuan Kewirausahaan dan Persepsi Peluang Kerja di Bidang Akuntansi dengan Minat Berwirausaha. Jupe UNS, Vol. 2, No. 1, Hal 131 s/d 145.

Yuwono, Susatyo dan Partini. 2008. Pengaruh Pelatihan Kewirausahaan Terhadap Tumbuhnya Minat Berwirausaha. Jurnal Penelitian Humani. Volume 9. No.2 